\section{Nawiedzenie (malarstwa chrześcijańskiego)}

Jean-Luc Nancy

TEKSTY DRUGIE 2016, NR 2, S. 169-190

DOI: $10.18318 /$ td.2016.2.9
Źródło: Jean-Luc Nancy, Visitation (de la peinture chretienne), Lignes Fictives, Galilée, Paris 2001. Druk za zgodą wydawnictwa Galilée.

$\Theta^{\mathrm{z}}$ ztuka nigdy nie upamiętnia. Nie jest tworzona po to, by zachować pamięć, a kiedy realizuje się w postaci historycznego pomnika, nigdy nie stanowi upamiętniającej części dzieła. Dowodem na to, o ile trzeba tu czegokolwiek dowieść, jest fakt, że istnieją pomniki bez sztuki, ale żadne dzieło sztuki nie jest pomnikiem jako takim. Jeśli sztuka w ogóle utrzymuje związek z pamięcią, to chodzi tu o dziwną pamięć tego, co nigdy nie odkłada się we wspomnieniu, a więc o coś, co nie podlega ani zapomnieniu, ani pamięci (jako że nigdy tego nie przeżyliśmy ani niczego o tym nie wiemy), co wszelako nigdy nas nie opuszcza. Chodzi tu zatem o pamięć, która pod nazwą piękna czy wzniosłości, potworności czy przyjemności, jasności czy poruszenia, jest dla nas od dawna (od zawsze?) „blaskiem prawdy” (Platon), czyli zarazem jej jasnością oraz błyskiem, błyskawicą, jej oczywistością oraz zagadką. Z owej pamięci nie rodzi się żadna anamneza, w zamian za to każdy gest artystyczny pragnie wedrzeć się do pamięci, przybliża się do tego, by się o nią otrzeć, a także, o ile to konieczne, by spłonąć bądź rozpaść się na kawałki. Sztuka jest tym, co wykracza w stronę tego, co ją

Jean-Luc Nancy - ur 1940, jeden z najwybitniejszych współczesnych filozofów francuskich. Jego myśl stanowi twórcze rozwinięcie projektu dekonstrukcji Jacques'a Derridy, który poświęcił Nancy'emu książkę (Le toucher, Jean-Luc Nancy, 2000). Przez wiele lat współpracował z Philippem Lacoue-Labarthem. Autor kilkudziesięciu prac. Po polsku ukazały się: Corpus (1999, przeł. M. Kwietniewska) oraz Rozdzielona wspólnota (2002, przeł. M. Gusina iT. Załuski). 


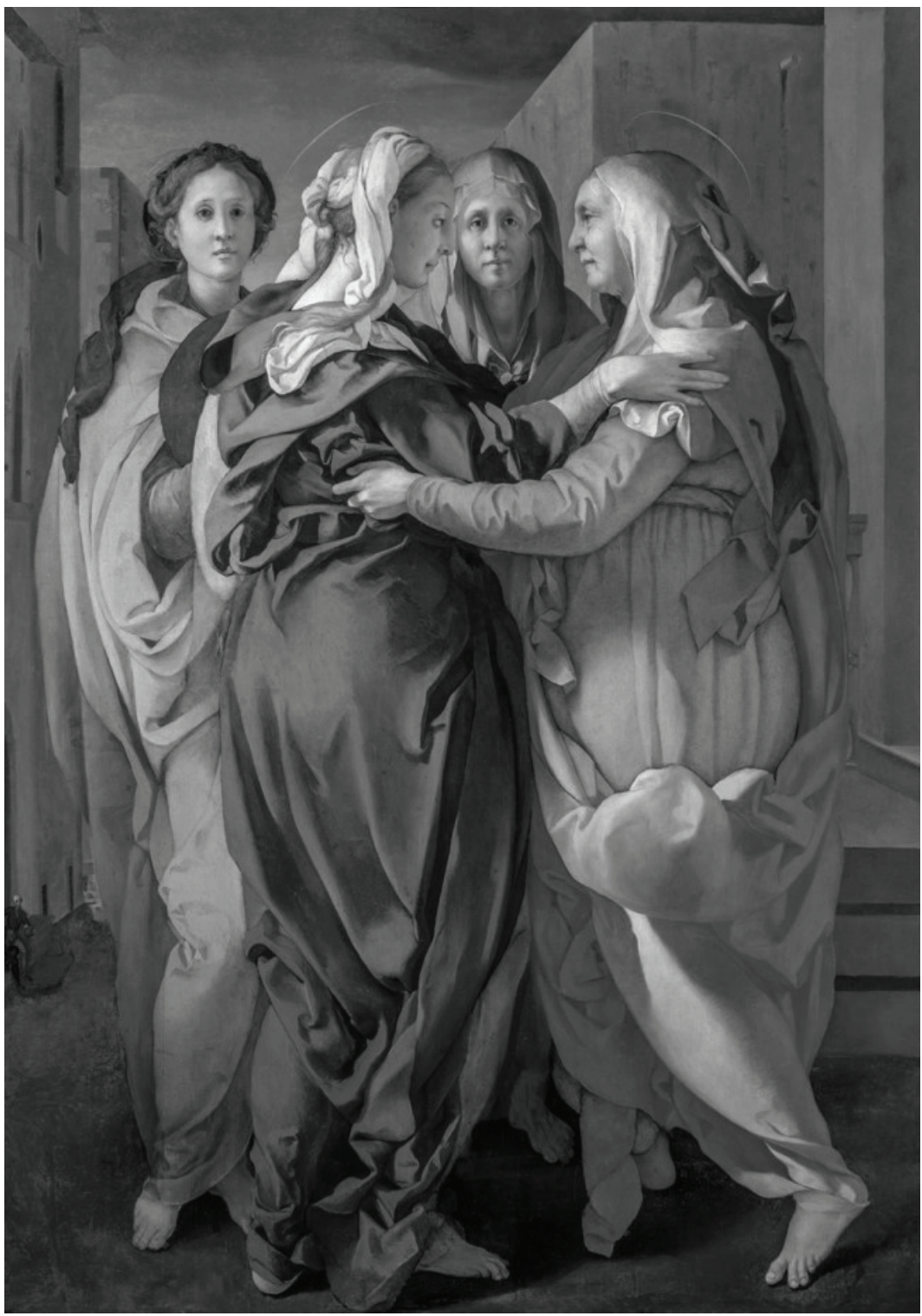

Jacopo Pontormo (właśc. Jacopo Carrucci), Nawiedzenie Najświętszej Marii Panny, 1528-1529, San Michele, Carmignano.

http://rcin.org.pl 
poprzedza, bądź w stronę tego, co po niej następuje, a w rezultacie również w kierunku własnych narodzin i własnej śmierci. Zawsze istnieje sztuka zanurzająca się w głąb siebie bądź taka, która występuje poza siebie.

To, co odwieczne, jest w ścisłym sensie czymś, co poprzedza narodziny, stanowi nieobecność wszelkiego wspomnienia, w stronę którego nieustannie wznosi się nieskończona pamięć, nad-pamięć czy raczej n i e - p a m i ęć'. Na pomniku lub poza nim, tzn. poza "sobą" $i$ wewnątrz "siebie" oraz na zewnątrz i wewnątrz tego, co może zostać upodmiotowione: zaświaty lub inny świat (w znaczeniu śmierci), nie coś poza światem, lecz coś obecnego tu i teraz.

Przedstawienie tego, co sytuuje się przed narodzinami - przed w s z el k i m i narodzinami, avent, jak głosi Kościół rzymskokatolicki, lub narodzinami samych narodzin, narodzinami w narodzinach jako takich - występuje w chrześcijańskiej przypowieści w scenie znanej pod nazwą „Nawiedzenie” (scenie, której źródła z pewnością są niepamiętne). Scena ta przykuła uwagę malarzy; to bardziej scena kultu niż scena teologiczna, scena emocji i zaskoczenia, obcości dziwności w porównaniu z bardziej kanonicznymi i dogmatycznymi scenami, które ją otaczają i się z nią krzyżują. Mam tu na myśli sceny: „Zwiastowanie” oraz „Narodzenie”.

Spójrzmy na Nawiedzenie namalowane przez Pontormo. (Chodzi mi o obrazy znajdujące się w kościele Carmignano, a nie o wcześniejsze, które można znaleźć we Florencji) ${ }^{2}$.

Po przyjęciu anioła Zwiastowania Maryja dowiaduje się, że jej kuzynka Elżbieta stała się brzemienna, choć jej zaawansowany wiek nie dawał nadziei na zajście w ciążę. Jest już w szóstym miesiącu. Maria składa jej wizytę. (Nie podano żadnego wyjaśnienia. Wszystko dzieje się, jak gdyby cud musiał się potwierdzić przez swoje podwojenie). Visitatio w łacinie kościelnej to nie zwykłe odwiedziny: to postępowanie mające na celu uświadomienie sobie czegoś, zbadanie i doświadczenie czegoś. W pewnych kontekstach wspomniane słowo może oznaczać to, co pozostało jako efekt nawiedzenia przez Boga - łaskę lub wystawienie na próbę.

Istotnie, kiedy Maria (widoczna z lewej strony obrazu) przybywa do domu Elżbiety i pozdrawia ją, ta „została napełniona Duchem Świętym. I zawołała głosem wielkim, mówiąc «Błogosławionaś ty między niewiastami

1 Por. Immemory, CD Chrisa Markera (Centrum Pompidou 1998). W dziele tym nie chodzi o brak pamięci, lecz o wykroczenie poza pamięć, o pamięć uwalniającą się od siebie samej.

2 Równocześnie należałoby obejrzeć The Greetings, instalację wideo Billa Violi stworzoną na Biennale w Wenecji w 1995 roku, która przenosi, odgrywa czy re-prezentuje obraz Pontormo. 
i błogosławiony owoc żywota twojego. A skądże mi to, że przyszła matka Pana mego do mnie? Oto bowiem, skoro zabrzmiał głos pozdrowienia twego w uszach moich, skoczyło z radości dzieciątko w łonie moim»"3. Na co Maryja odpowiada formułą zwaną Magnificat. Scenę tę możemy odnaleźć w Ewangelii św. Łukasza ${ }^{4}$, ewangelisty dzieciństwa, będącego również patronem malarzy, ponieważ - jak głosi legenda - jest autorem portretu Maryi i wielu artystów przedstawiało go podczas sporządzania tego obrazu (jego księga przypomina zatem portret, wierny obraz). Syn Elżbiety to Jan Chrzciciel, „ten, który poprzedza”, a zarazem ten, który w ciemnościach łona „skacze” i drży z radości na głos tej, która poczęła z Ducha Świętego.

Scena ta jest zatem całkowicie i w ścisłym sensie duchowa czy pneumatyczna: to, co istotne, jest ukryte przed oczami i wyraża się poprzez głosy, przez dotknięcie głosu, który trwoży - poprzez swoją niewidzialność - samo wnętrze ciała i nienarodzonego. Pojawia się tu zatem błysk ducha między dwiema nieobecnymi obecnościami, dwoma istnieniami w stanie wycofania się z egzystencji - o tyle odwiecznymi, o ile są one nieoczekiwane i niemożliwe - w zamkniętym łonie bezpłodnej kobiety i dziewicy. W pewnym sensie to właściwe wyzwanie dla malarstwa, przynajmniej o tyle, o ile malarstwo w istocie pozostaje zawsze powołane do tego, by stać się wyzwaniem dla widzialności. Można by więc powiedzieć, że wraz z tym problemem czy tematem to, co niewidzialne, musi rzucić nam się w oczy.

Malarz zmierza prosto do sedna sprawy, do serca rzeczy, tzn. do tajemnicy. Nie usuwa jej ani jej nie rozwiązuje, ani też nie czyni z niej obiektu wiary, lecz - by tak rzec - instaluje się w niej. Tym, co otrzymujemy na początku (chyba że się od razu w to zanurzymy), jest wielka plama skontrastowanych ze sobą i wibrujących kolorów. Wszystkie one zostają wysunięte na pierwszy plan w intensywny sposób, właściwy Pontormo: ostre i ciężkie tony stają się zakwaszone i rozcieńczone w falach światła przychodzącego nie wiadomo skąd, lecz z pewnością nie z zimnego i ciemnego otoczenia, od którego ten wir barw oraz ruch pofałdowanego i pozaginanego materiału odrywa się, unosząc ze sobą wszystko inne. Zwłaszcza plama światła wyróżnia się do tego stopnia, że można sądzić, iż wydobywa się z reflektora oświetlającego brzuch Elżbiety; to miejsce, gdzie samo światło nadaje jasnozielonemu kolorowi żółtawy

3 Łk,40-45. Pismo Święte Starego i Nowego Testamentu w przekładzie polskim Jakuba Wujka, Kraków 1962.

$4 \quad 七 k$ I,39-56. Scena ta jest nieobecna w trzech innych kanonicznych Ewangeliach, lecz ma kilka odpowiedników w ewangeliach apokryficznych. 
odcień; to przestrzeń, w której, dziecko „skoczyło”. (Maryja wtóruje temu poruszeniu. W Magnificat powiada: „Wielbi dusza moja Pana”. To oddźwięk jej własnego głosu, który w ten sposób do niej powraca).

Wszystko porusza się w tym skłębieniu i spiętrzeniu tkanin przesyconych fałdami, zakrzywieniami oraz obrzmieniami, w których postaci zostają raczej uszlachetnione i wywyższone niż unicestwione. Dokonuje się to jak gdyby przez zastygły wiatr oraz powietrze rozświetlające i powiększające dwa brzuchy ciężarnych, między którymi i wewnątrz których oddycha duch. Cały ciężar zostaje tu zawieszony.

Owe łona dotykają się bez dotyku. Wyraźnie zaznaczone krzywizny obu mogłyby pozostać lekko podzielone na dwa odcienie zieleni, gdyby nie drobny fragment szaty zakrywający głowę Elżbiety, zwisający i zasłaniający owe linie, aż do punktu, który wydaje się pomyślany rzeczywiście jako miejsce styczne lub jako "przejście do granicy” w rachunku różniczkowym. Od tego punktu w górę, w stronę wyprostowanego ramienia Elżbiety na jej ciemnopomarańczowej szacie, w centrum malowidła zarysowuje się trójkąt. Trójkąt ten rozszerza się wyżej, poprzez spiętrzenie pofałdowanych linii ramion oraz rozmieszczenie trzech głów ${ }^{6}$.

Ten potrójny i trynitarny system (nadający kobiecy charakter Trójcy Świętej) określa rytm między dwoma, złączonymi w jedno, ruchliwymi ciałami matek, podczas gdy ich stopy zdają się tańczyć na ziemi lub ledwie jej dotykać, między nimi zaś znajduje się nieruchoma głowa służebnicy Elżbiety. To równocześnie scena krzyżujących się spojrzeń: dwie kobiety uważnie

5 W języku francuskim ten fragment brzmi "mon esprit tressaille de joie", gdzie czasownik "tressaillir" pojawia się i w scenie Nawiedzenia, i w Magnificat i oznacza dosłownie "drżeć z radości". Nancy czyni użytek z tej wieloznaczności. W języku polskim, oczywiście, nie znajdziemy tej gry słów [przyp. tłum.]

6 Łona dwóch kobiet często dotykają się w dziełach tych malarzy Nawiedzenia, którzy - z pewnością zgodnie z ich własną symboliczną intencją - przyjmują model pocałunku, a nie wzorzec zdystansowanego uścisku dłoni lub przyklęknięcia Elżbiety. (Pontormo używał wcześniej tych dwóch innych modeli). Model opierający się objęciu wynikałby ze zmiany znaczenia greckiego słowa aspasmos, oznaczającego radosne, ciepłe, uniżone pozdrowienie. Jeśli chodzi o schemat układu czterech głów, Pontormo zaczerpnął go z Czterech czarownic Dürera, powtarzających z kolei - jak zauważył Panofsky - motyw trzech Gracji i wiązał go również z Dürerowską Łaźniq kobiecą. Należałoby zrekonstruować ciąg zależności między seksualnością, diabolicznością, mitologicznością i cudownością w całym ich pokrewieństwie, stanowiącym także ramę dla malowidła. Skądinąd ciekawe wydaje się, że w kilku tradycjach Wschodu dzieci przedstawia się w dwóch brzuchach jako przezroczyste. Por. L. Réau Iconographie de l'art chrétien, PUF, Paris 1957, t. 2, s. 195. 
patrzą sobie nawzajem w oczy, każda z nich spogląda w serce drugiej, jak gdyby razem rozpoznawały to, czego nie można ani ujrzeć, ani wypowiedzieć, a co je silnie porusza (a ściślej: chodzi o to, co nie może zostać ani ujrzane, ani wypowiedziane, ale ku czemu nie przestaje się zmierzać - tu właśnie mieści się to, co odwieczne i niepamiętne). Wszelako tych dwoje przenikających się oczu (z każdego profilu widać tylko jedno oko), dotykające się niczym łona, w pewnym sensie odbija się - w samym środku obrazu - w oczach służebnicy, które nagle nas unieruchamiają. Oczy te paraliżują nas od zawsze niejako już w samej głębi sceny czy raczej spoza owej głębi ciemnego nieba podkreślonego linią muru, którego perspektywa przechodzi dokładnie przez szczyt zasłoniętej twarzy kobiety.

(Jednym z problemów tego obrazu jest próba naruszenia perspektywicznej przestrzeni - oraz jej ukierunkowanego spojrzenia - tak, aby obrócić ją na bok, okręcić i zapętlić, by tak rzec, rozmazać ją wokół... Nie chodzi już jedynie o kwestię, jak i gdzie będzie skierowany wzrok, lecz raczej o rozpostarcie i rozlanie się widzenia oraz postrzegania).

Równocześnie rytm znów zostaje zmieniony: spojrzenie zwrócone do nas podwaja się z kolei w spojrzeniu służebnicy Maryi. Każda z dwóch służebnic, wyraźnie odpowiadająca wiekiem, fryzurą i kolorami swojej pani, przenosi na nas - poprzez spojrzenie frontalne, będące jawnie spojrzeniem samego malowidła - intymne, nieskończone i dotkliwe spojrzenie, za pomocą którego odwiedzają się dwie matki. Unieruchomione spojrzenia służebnic (co jest tym bardziej godne uwagi, że na jednym ze szkiców patrzą z boku) szukają i oczekują naszego spojrzenia, jak to często bywa w przypadku portretów ${ }^{7}$. Tym, czego należy więc szukać, tym, czego szuka samo malowidło, jest wzajemne nawiedzenie widza i obrazu, jest pewien p o d mi o t malarstwa. Należy zobaczyć jego konkretny p o d m i o t, będący zarazem opracowanym tematem oraz obecnością ukrytą w łonie wraz z jej odwiecznym źródłem, po to, abyśmy potrafili zobaczyć niewidzialne i umieli „czynić pamiątkę”, sięgającą czasu sprzed narodzin (lub z drugiej strony: śmierci).

A jednak wraz z pojawieniem się drugiej służebnicy scena zwraca się i przemieszcza również w lewą stronę, jak dzieje się skądinąd w Czterech czarownicach Dürera. Po lewej stronie obrazu mieści się rodzaj powtórzenia głównego motywu: pod łokciem młodej służebnicy (kawałek beżowego materiału

7 W tym miejscu można by dookreślić, że owe "służebnice" mogłyby być również - W innego rodzaju modalności podwojenia - dwiema przyrodnimi siostrami Maryi, co można czasem zauważyć na niektórych przedstawieniach Nawiedzenia. 
otoczonego różem) zarysowuje się czerwony trójkąt, który - dzięki swemu kształtowi, wymiarom i umiejscowieniu - daje się odczytać jako powtórzenie centralnego pomarańczowego motywu. Dwa razy boski trójkąt skonstruowany na obrazie łona (obraz trynitarny i kobiecy). Jest trochę tak, jak gdyby dzięki młodej replice Maryi centralną obejmę zwierającą postaci obrazu, czyli styczny do tych postaci, zamknięty i ostry trójkąt, dało się rozpleść i rozwinąć poprzez powtórzenie całej struktury, poprzez repetycję prowadzącą gdzie indziej lub zgoła nigdzie.

Poza trójkowym schematem uwidacznia się coś innego, co przywraca scenerię i tło obrazu i ożywia, jakkolwiek nieznacznie, jego linearną architekturę. Dwie ledwie widoczne sylwetki, celowo pogrążone w przesadnym dystansie i wyjaskrawionych półcieniach, odkrywają fakt własnego istnienia. (Postaci te są równie małe jak homunkulusy ukazane in utero w niektórych reprezentacjach Nawiedzenia). Aby wyróżnić każdy ze szczegółów, należy zbliżyć się do punktu, w którym dotykamy, ogólnie biorąc, łona malarskiego przedstawienia, jego wnętrza. W stronę tego miejsca rozwija się spirala zielonego turbanu służebnicy, z tego miejsca można też spostrzec, w samej głębi obrazu, jedynie małą plamę szarego światła. Przypomina to rodzaj otwarcia (i faktycznie jest to ulica prowadząca na lewo); jest jak dyskretny sygnał naprowadzający spojrzenie na słabe światło w głębi: światło wstępuje do miasta - światło z wnętrza. Owa plama świtu czy zmierzchu została rozmieszczona niczym puste pole lub prześwit, zanikający punkt odwrotnie symetryczny do przestronnego wejścia, które wraz z podniesionym progiem otwiera się na ciemność znajdującą się za plecami Elżbiety ${ }^{8}$.

Znajdujemy tu dwie sylwetki, nieco z dala od tego punktu, blisko krawędzi malowidła, przed wejściem, którego sklepienie - podobne do łuków okien znajdujących się powyżej - wskazuje na florencki charakter tła. Są to dwaj mężczyźni o pospolitym wyglądzie, jeden trzymający w ręku nóż i bochenek chleba, drugi - butelkę?. Jeden patrzy na drugiego, tamten patrzy na nas

8 Owo światło wdzierające się w głąb malowidła pokrywa również jego lewą stronę i kształtuje cienie rzucane na pierwszy plan przez stopy oraz szaty. W ten sposób światło to podkreśla - na co zwrócił mi uwagę Paul Guérin - dwoistość przestrzeni ostro podzielonej na głębię i pierwszy plan, lewą i prawą stronę, oraz zaburza równowagę przestrzeni symbolicznej.

Takie jest przynajmniej, dość prawdopodobne, przypuszczenie, na którym oparłem swoją refleksję w trakcie szczegółowych badań. Proponuję zatem nie tylko osobistą interpretację, lecz przede wszystkim osobistą wizję w fizykalnym znaczeniu tego słowa. Detal, o który chodzi, trudno precyzyjnie wyodrębnić. Muszę przyznać, że rozróżniam nóż jedynie na reprodukcji zawartej w książce Costamagny (por. poniżej), w której ten fragment obrazu jest dużo jaśniejszy. 
(być może tylko jednym okiem), w skróconej wersji wielkiej sceny spojrzeń. Z zamierzenia oni sami są ledwie widoczni, zanurzeni w niejasności, jakby konieczne było ich opuszczenie i pominięcie (nawet wtedy, kiedy zauważamy, że jest to konieczne), zapomnienie o nich nawet wtedy, gdy wiemy, że jest to konieczne: pozostają zanurzeni w głębi malowidła jak dzieci w głębi łona i tak jak one - niepamiętne. Możliwe również, że mężczyźni z obrazu cierpią lub zostali zranieni (prawdopodobnie jeden z nich ma wyłupione oko), co może odsyłać zarazem do wojny oraz do ofiary. (Powrócę tu jeszcze do tej kwestii) ${ }^{\mathbf{1 0}}$.

Wraz z chlebem i winem - a także wraz z tymi mężczyznami, którzy je trzymają i którzy różnią się pod każdym względem (rozmiaru, płci, światła) od porażającej światłem grupy kobiet - wcielenie (w podstawowym znaczeniu) uwidacznia się po raz drugi, lecz w tym wypadku w sąsiedztwie ofiary i śmierci. Coś śmiertelnego nadchodzi z głębi obrazu, (być może) podobnie jak ze spojrzenia - łagodnego, lecz ciążącego - skierowanego na nas przez starszą ze służebnic. Młodsza zaś, wpatrując się w oglądających obraz, raczej zaprasza nas do patrzenia, jak to, co poprzedza życie oraz to, co następuje po nim - inny akcent śmierci - zostało w wplecione w to, co odwieczne i niepamiętne. Ten splot nie jest ani obecny, ani nieobecny, lecz zostaje przeniesiony lub rzucony w chaos przesłon i ramion, kolorów, rodzajów światła i rozmaitości spojrzeń. To splot absolutnie wewnętrzny - interior intimo meo - w którym zanurzają się w siebie i przenikają wzajemnie spojrzenia dziewicy i bezpłodnej kobiety, zatapiając się tym samym w podwójną

Bezpośrednia wizja ukrywa ów kawałek, o ile w ogóle on istnieje (płótno mogłoby być w tym miejscu rozmazane). Tak samo bochenek chleba mógłby być kapeluszem... Być może przedstawienie wina jest najmniej niepewne. Komentatorzy, u których szukałem wskazówek, nie mówią o przedmiotach (które wszelako dają się od siebie odróżnić, nawet jeśli są trudne do zidentyfikowania), trzymanych przez postaci. Zauważają oni dysproporcje między tymi postaciami na malowidle, wspominają, że mogą one przedstawiać Józefa i Zachariasza, dwóch mężów niekiedy kojarzonych z tą sceną (choć ich pokazanie czyni tę scenę trochę niemożliwą). Por. S. Nigro Pontormo, Schirmer-Hasel, München 1993; A. Forlani Tempesti, A. Giovanetti Pontormo, Octavo, Florence 1994. P. Costagama (Pontormo. Catalogue raisonné de l'œuvre peint, Electa, Milan 1994) o nich nie wspomina. Całkiem niedawno Maria-Luisa Antonelli z Florencji, zagadnięta przez Antonellę Moscati, zasugerowała mi rzecz następującą: owych dwóch mężczyzn to sam Pontormo (siedzący) oraz Bronzino, jego uczeń. W końcu Paul Guérin pokazał mi, że w tym samym miejscu, w Czterech czarownicach Dürera pojawia się Diabeł... Tak czy inaczej, przynajmniej w tej niewielkiej scenie - tak znaczącej właśnie dlatego, że zostaje wymazana i pozostawiona w cieniu - znajduje się zawsze dowód ukrycia, a zatem wystawienia. 
obecność - odgrywaną przez dwóch mężczyzn w głębi obrazu - obecność, niepochodzącą z jakiegoś miejsca ani nieprzybywającą z żadnego czasu (ani także z żadnej dającej się umiejscowić formy poczęcia), z żadnego pokolenia, lecz w istocie nadchodzącej z drugiej strony czasu i przestrzeni. Podwójna obecność zwraca się w kierunku tej drugiej strony, tak jak podwójne przenikanie się spojrzeń zostaje równocześnie odwrócone ku nam w podwójnym spojrzeniu. Przecina ono na pół scenę widoczną na płaszczyźnie malowidła, jak gdyby owa płaszczyzna przeszywała na wskroś dwa łona. Z nich właśnie niejako wyłania się widok, poprzez który to, co odwieczne, nam się przypatruje i, by tak rzec, widzi nas, zbliżających się do obrazu, lub nawet ofiarowuje nam własne nawiedzenie, z głębi ciemnego burzowego nieba, które rozdziera słaby błysk Maryjnej aureoli.

Chleb i wino, ów ciemny szczegół z malowidła odłącza się od niego, jako że detal tego typu jest obciążony, a nawet przeciążony znaczeniami, i ukazuje się, aby ukryć intensywność (gęstą oraz zwartą), która równoważy całe rozszerzenie pierwszego planu i może nawet stać się prawdziwym katalizatorem tego wrzenia kolorów (chyba że jest to strącony osad, resztkowy konglomerat: oba kierunki interpretacji są uzasadnione). Chleb i wino mają zatem drugą wartość łączącą się z wartością wcielenia (obecność boga w łonie kobiety. Nieco później wrócę do tego „detalu detalu”): są to ciało i krew Chrystusa podzielone między uczniów podczas Ostatniej Wieczerzy w geście, do którego powtórzenia "na swoją pamiątkę" wzywał człowiek-bóg (cały czas odnoszę się do Ewangelii św. Łukasza). Gest rozdzielania chleba i wina dla całego chrześcijaństwa stanowi upamiętnienie wcielenia, tak jak - poprzez chrześcijaństwo - gest ten jest również pamięcią o wiele dawniejszej, w istocie niepamiętnej sakralności (dionizyjskiej, rolnej...), której echo rozbrzmiewa długo po czasach Pontormo, już niemal poza chrześcijaństwem, w następujących wersach Hölderlina:

Brot ist der Erde Frucht, doch ists vom Lichte gesegnet, Und vom donnernden Gott komet die Freude des Weins.

Chleb jest owocem ziemi, ale i z mocy światła, A radość budzona przez wino pochodzi od boga."

11 F. Hölderlin Co się ostaje ustanawiaja poeci - wiersze wybrane, przeł. A. Libera, Znak, Kraków 2003, s. 156-157 [przekład zmieniony - przyp. tłum.] 
Wiadomo również, w jaki sposób interpretacja eucharystycznej figury odegrała decydującą rolę w historii chrześcijaństwa. Na pierwszym, podstawowym poziomie owo upamiętnienie wykracza poza porządek pamięci: przywraca rzeczywistą obecność człowieka-boga oraz rzeczywistość jego wcielenia poprzez tych, którzy spożywają go w eucharystycznej postaci chleba i wina (tzn. w świętej postaci wcielonego boga). Jednak wraz z reformacją sposób tej obecności stał się dwojaki: Kościoły rzymskokatolicki i wschodni wyznają wiarę w rzeczywistą obecność eucharystycznych substancji chleba i wina, natomiast Luter zachowuje ich substancję, w której chroni się obecność duchowa.

Tak więc okazuje się, że owo „Nawiedzenie” można odczytywać jako polityczno-religijną alegorię opisującą ruchy reformatorskie w Kościele. Ich czas to okres, w którym Florencja, ledwie przywróciwszy sobie status republiki, cierpiała z powodu ataków papieskiego sojusznika, Karola V (po zdobyciu Rzymu).W tym okresie florenccy artyści zasadniczo byli nastawieni bardzo patriotycznie. Michał Anioł ponownie oddaje się w służbę Republice i udoskonala jej umocnienia (sądzi się, że prawa strona malowidła Pontormo wraz z jej potężnym murem stanowi odniesienie do pracy Michała Anioła) ${ }^{12}$. Cele polityczne mieszają się tu z religijnymi: od Savonaroli Florencją wstrząsało wiele prób reformy chylącego się ku upadkowi Kościoła rzymskokatolickiego. Miasto widziało nawet kilka pojedynczych konwersji na luteranizm. Z pewnością Pontormo nie składa tutaj deklaracji akcesu do „kościoła zreformowanego", lecz można sobie wyobrazić, że wyrażane przez niego opinie mogły mieć charakter nieco reformistyczny ${ }^{13}$. Sugerowano nawet, że „Nawiedzenie” należałoby widzieć jako jego własne odwrócenie: Elżbieta, wkraczając przez Porta Romana, składa wizytę Maryi, przyszłej matce Jezusa, Rex florenti populi (hasło powtarzane w epoce Savonaroli).

"Nawiedzenie" interpretuje się niekiedy jako symbol przejścia między Starym a Nowym Testamentem lub między Synagogą a Kościołem. W ten sposób na obrazie nowy Kościół mógłby przejąć rolę po Kościele rzymskim lub doprowadzić do jego odrodzenia. Z tej perspektywy chleb i wino byłyby tu niejako zawieszone między transsubstancjacją a oddzieleniem od substancji. Lecz zarówno z jednej, jak i z drugiej strony (nawet rozpatrywanych

12 Por. P Constamagna Pontormo..., s. 54 oraz nr 59 katalogu znajdującego się tej książce. Wojna mogłaby tłumaczyć, dlaczego przynajmniej jeden z mężczyzn wygląda na rannego.

13 Przywołując wspomniany już model malowidła, zachowując wszelako wszelkie proporcje, można by przywołać pewne tendencje prereformistyczne u Dürera. 
łącznie) Pontormo zaprasza nas do przemyślenia - poza religijnym i politycznym sporem - tematu rzeczywistej obecności, ukrytej w samym sercu jego obrazu. Mielibyśmy tu zatem do czynienia z malarstwem jako takim: jego uderzający blask i siła, mieszczące w sobie prawdę tej obecności, kształtowałyby jej substancję lub skrywały w sobie jej tajemnicę, tak jak łona dwóch kobiet chowają owoce dwóch nieodgadnionych poczęć. W ten sposób, co było widać jak na dłoni nawet przy pierwszym pobieżnym spojrzeniu, wszystko zależy tu od obecności, promieniującej w nadmiarze kolorów i form, zarazem jednak nieskończenie intymne spojrzenia dwóch matek zagłębiają się w tę obecność. Lecz jeśli spojrzenie owo zostaje faktycznie natychmiast zwrócone - poprzez służebnice - w naszą stronę, to malowidło kieruje w naszą stronę i w nasze widzenie, w naszą wizję spojrzenie, które tworzy z nas substancję lub podmiot malarstwa bądź umieszcza w nas - poprzez namalowaną substancję - rzeczywistą obecność swego podmiotu (zarazem człowieka i boga, malarza i widza, reprezentacji i obecności). Pontormo w geście, świadczącym o jego niezwykłej arogancji wobec religii, której źródłami równocześnie manipuluje, zdaje się odsuwać w cień chleb i wino. Mogłyby one stać się tu szyfrem obecności zarazem ukrytej i wyeksponowanej - ukrytej w swojej ekspozycji - której rzeczywistością ostatecznie okazuje się wyłącznie malarstwo. Leży to u podstaw znaczącego gestu odwrócenia się od religijności ${ }^{14}$.

To zawieszenie czy ta niejasność między dwoma istotnymi odniesieniami malowidła - do prawdy religijnej oraz do prawdy malarskiej - występuje między dwoma znaczeniami pamiątki po komunijnym połączeniu. Po stronie katolickiej mielibyśmy do czynienia z upamiętnieniem dosłownie ożywiającym wydarzenie, które odtwarza pełną rzeczywistość, po stronie reformacji pamięć skierowaną w stronę czegoś, co nie daje się ponownie urzeczywistnić, jako że jest realne raczej w sposób nieskończony. Jedno i drugie podejście pokazuje, że w tym wypadku zawsze chodzi o kwestię tego, co odwieczne, tzn. tego, co nie odnosi się do przeszłości, lecz jedynie do realności w wiecznym

14 lle tego rodzaju gestów można znaleźć w malarstwie religijnym?... Istnieje pokusa, by stwierdzić, że niewątpliwie nie istnieje malarstwo, którego nie przepełniają takie gesty, z tego prostego powodu, że chodzi tu o sztukę, a nie religię. Dodaję w tym miejscu uwagę poniewczasie: Heidegger w krótkim komentarzu do Madonny Sykstyńskiej Rafaela wiąże transsubstancjację z figuralnym przedstawieniem boskiego wcielenia (choćby nawet $w$ tym przypadku malowidło nie dawało filozofowi żadnych wyraźnych podstaw do takiego zestawienia, jako że nie zawiera żadnego odniesienia do komunii). Należałoby przeanalizować, jakie są dokładnie jego cele: czy podstawia on przedstawienie malarskie pod kult religijny, czy odnosi je do siebie wzajemnie w imię wyższej istoty lub...? Zostawiam te kwestie do rozwikłania Philippe'owi Lacoue-Labarthe'owi, który pracuje nad przywołanym tekstem Heideggera. 
powrocie lub w niezmiennej obecności. To, co odwieczne, stanowi to, co bezgranicznie dawne, a w ten sposób ostatecznie obecne. Logika ta dotyczy jednak przede wszystkim aktu malarskiego: nie upamiętnia on sceny z Pisma Świętego, nie wykorzystuje problemu obecności, która nie jest czymś, co należy przypomnieć, lecz przeciwnie: stanowi obecność, będącą wezwaniem „w” malowidle, w jego fakturze i świetle, bezpośrednio w intymności jego promieniejącej powierzchni. Wzywa ona, tak jak Maryja wzywa Elżbietę. Całe malowidło jest milczącym, lecz wibrującym echem tego głosu - to drżenie, w którym rozpala ono kolory i krzywizny obrazu.

(Czy dałoby się podjąć refleksję nad tym, że to malarskie uwypuklenie pierwszego planu odsuwa w cień rzeczywistość religijną, która została zredukowana do zwykłego spożywania pokarmów? Czy udałoby się przemyśleć sytuację, że malarstwo rozwija się aż do punktu, w którym odwracają się role między nim samym a tym, co ma reprezentować bądź symbolizować?).

Kiedy powrócimy teraz do tego, co znajduje się na pierwszym planie, lecz cały czas po lewej stronie, na której zostaje odegrany drgający rytm wraz z całą subtelną relacją ciała do ducha (człowieka do boga, cielesnej tkanki obrazu do ducha obecności), rozpoznamy jeszcze jeden zaskakujący szczegół. Nieco niżej, między oliwkowozieloną szatą Dziewicy a różową, należącą do jej dublerki, znajduje się pukiel włosów Maryi.

Kiedy oglądamy włosy na głowach obu postaci Maryi, widzimy, że wysuwają się spod chust i kapryśnie falują, co można dostrzec zwłaszcza w kosmyku opadającym na ramię Dziewicy. W odróżnieniu od zasłoniętych głów pozostałych dwóch kobiet ich włosy wskazują zatem nie tylko na młodość, lecz - w samej tej młodości - na zmysłowość, którą można by przeciwstawić konwencji religijnej. Nie znam innego przedstawienia (autorstwa Pontormo) Marii Dziewicy o włosach tak zwiewnych i drgających (inna forma „drżenia z radości"?), natomiast znalazłem obraz kobiety w Zdjęciu z krzyża, której włosy opadają na plecy i którą z tego samego powodu musi być Maria Magdalena, czy na portrecie Francesci Capponi, również przedstawionej jako Maria Magdalena. Lecz wraz z nią, jak wiadomo, pojawia się figura grzechu... ${ }^{\mathbf{1 5}}$.

Włosy, zwisające tu bardzo nisko, których wygląd (można by rzec: ich odrastanie) jest zdumiewający, o ile nie absurdalny, pozwalają falować

15 Należałoby również wspomnieć o Noli me tangere Pontormo, gdzie Chrystus powstaje z grobu i zakazując Marii Magdalenie dotykania go, dotyka (ledwie...) kobiecych piersi w tym samym geście, którym ją odpycha. Można dodać także, że czarownice u Dürera noszą warkocze opadające na ich nagie plecy. 
końcówkom kosmyków tuż przy pośladkach Dziewicy, na wysokości wzgórka łonowego jej dublerki. Znów: szczegół został tu namalowany po to, by przyszpilić pewnego rodzaju osobliwość, która nie może, z chwilą, w której się ją zauważy, pozostać długo nieokreślona. Oczywiście podział na ciało i ducha staje się w tym miejscu znów zamazany, a w geście malarskim powtarza się szczególna ceremonia mistycznych zaślubin, w wyniku których łono dziewicy zostało zapłodnione. Właśnie w tym miejscu, w tajemnej grze włosów, wskazujących na siebie nawzajem, zostaje pokazana płeć. Jedność boskiego ducha z ludzkim ciałem tworzy się tu z samej materii; stanowi splot nie tylko tych włosów, lecz całego wielkiego zamętu, wirującej - ruchomej i zawieszonej - sfery, zabarwionych fosforycznie kawałków sukna. Ciało Dziewicy można rozpoznać dzięki jego widocznemu zarysowi, z pewnością nie na zasadzie "rozbierania wzrokiem”, lecz o wiele bardziej realnie: jak gdyby cała wielka opalizująca spirala, w której grupa z malowidła znika, była samym tym łonem, jego otwarciem oraz głębią, pieszczotą i światłem, ciałem dotykalnym w oczach odwiecznej rozkoszy.

(Jeśli jednak w ten sposób można patrzeć na płeć Dziewicy, nie sposób zarazem nie dostrzec, że jeden z mężczyzn znajdujących się w głębi frontalnie pokazuje - tym razem bez cienia wątpliwości co do szczegółów - rozporek zgodny z panującą ówcześnie modą: dobrze widoczny i wypełniony swoją zawartością trójkątny obiekt, odsyłający do innego trójkąta otwartego w środku malowidła...)

Trudno jednak przy tej okazji nie pomyśleć również o pędzlu malarza, stosującego subtelne jasne pociągnięcie. W tym samym miejscu, ten sam jedwab i te same włosy, w ten sam sposób i z tą samą m a ni e rą (by użyć terminu kojarzonego często z Pontormo oraz kilkoma innymi artystami) zaczynają się mieszać - plątanina tyleż ulotna, co nieustępliwa - ciało, duch, życie, mężczyzna (kobieta) i bóg, łaska i grzech, światło i tekstura, kolor i krzywizna, reprezentacja i to, co nie daje się przedstawić - a także jedna płeć z drugą.

Ten zamęt rozpoczyna się i kończy wraz z malarstwem oraz jako malarstwo. Prawda odwiecznej intymności to nic innego, jak owo „wyrzucenie naprzeciw nas", to rozprysk kolorów we wzburzonym rozlewisku, całe to malowidło niczym łono lub oko otwarte na mieniące się wnętrze, to obraz, który zarówno na końcu, jak i u swych początków okazuje się niczym innym jak własną wyeksponowaną powierzchnią.

Ruch linii, odbijanie się spojrzeń, przejście kolorów w widmo lub w pryzmat - wszystko to jest w istocie „radosnym drżeniem” wyrosłym z ducha: spoza miejsca i czasu, poza religijnym oddaniem, pochodzącym z absolutnej 
zewnętrzności zwiniętej w głębi najbardziej wewnętrznego z wnętrz, a równocześnie okazuje się radością rozwijaną jako ogromna część wizji przedstawiającej rozlewającą się przestrzeń, ale także destabilizującej czas doświadczany poprzez te m p o tańczącej grupy.

To, co odwieczne, czyli miejsce i chwila pochodzenia oraz obecności, do której nie sposób powrócić, lecz która od z a w s z e - ju z - t u jest (łono matki i duch ojca, życie/śmierć, sens/prawda) zmieszały się z powstrzymaną obecnością malarskiego przedstawienia, z lekkim znieruchomieniem tańca, z pryzmatycznie pochwyconym światłem brzasku i zmierzchu, błyskającego nieba oraz sceny rozgrywającej się w szeleszczących tkaninach, w „płynnym przepychu kolorów"16 , będących źródłem rozkoszy. Wibrująca między dwoma głosami cisza i wciagająca nas nieskończona wymiana spojrzeń, pokazująca nam, że to, co mamy zobaczyć, całkowicie mieści się w głębi i na powierzchni, jest niczym innym jak owym niezmierzonym wznoszeniem się głębi na powierzchnię - głębi łona i niebios, głębi miasta i oczu. To głębia z a w s z e - juz - t u, a zatem zjawiająca się na nowo w przyszłości niczym powrót przeszłości dawniejszej niż wszelka przeszłość, jej n a wi ed z e n i e zawsze powtarzane w ruchu, w którym sama powierzchnia wznosi się, faluje i drży. Malarstwo odkrywa tu w sobie radość wypływającą z siebie samego i z czego poczyna wprost swą płaszczyznę oraz manierę, swój styl.

\section{Koda}

Podsumowując, wykonam jeszcze jeden krok w inną stronę malarstwa i w kierunku innego łona, innego miejsca poczęcia.

Madonna del Parto Piero della Francesca to słynne dzieło, wcześniejsze o około sześćdziesiąt lat od obrazu Pontormo (które zatem musiał on znać). Nie podejmuje ono tego samego tematu: to nie Nawiedzenie, nie są to również Zwiastowanie ani Narodziny (mimo że Madonna del parto została nazwana Madonna Narodzin, czci się ją pod tą nazwą i traktuje jako ochronę rodzących kobiet). Chodzi o scenę niemającą w żadnej mierze statusu przypowieści religijnej (to jak gdyby scena czystego malowania...): Maria Dziewica stoi z przodu, poniżej okrągły namiot, rozpostarty przez dwa anioły, rozsuwające zasłony z ciężkiego materiału. Lewa ręka Maryi opiera się na biodrze, natomiast prawa spoczywa na jej szeroko zaokraglonym brzuchu, gdzie jej błękitna suknia, przesunięta ze środka brzucha na przeponę (bez wątpienia

16 Wyrażenie użyte przez S. Nigro, w: tegoż Pontormo. 
dla wygody matki), ukazuje białą koszulę. Ręka, umieszczona na krawędzi tego długiego pęknięcia, znajduje się w nieokreślonej pozycji: może skupiać w sobie rozwijającą się tkaninę, ale także może się nie domykać, jak gdyby chodziło o przeniknięcie otwarcia, w którym - rzecz jasna - ta ręka przyciąga i ześrodkowuje spojrzenie ${ }^{\mathbf{1 7}}$. A zatem w tym miejscu również, ale w i inny sposób, niezaprzeczalnie uzyskujemy dostęp do niewidzialności w samym łonie: całe malowidło to właśnie otwarcie (a więc rzeczywiście: del parto), otwarcie jedna po drugiej wszystkich dróg prowadzących do głębi. To nic innego jak pikowany materiał namiotu, a zatem otwarta i wzniesiona do góry powierzchnia jako taka, którą podtrzymują w rękach aniołowie i Maryja. (Po lewej stronie jej brzucha podobne pęknięcie - niewątpliwie również oznaczające ulokowanie ciąży w obrazie - ukazuje nie jasność bielizny, lecz ten sam namiot jako zapikowaną głębię) ${ }^{\mathbf{1 8}}$.

Nie chcę w tej chwili zatrzymywać się na analizie tego malowidła. Chciałbym przejść wprost do o wiele nam bliższego dzieła, stanowiącego rodzaj pomnika: do jednego z serii płócien Simona Hantaï z 1975 roku, Tabula, noszącego tytuł ...del Parto.

Nie ma tu już Świętej Dziewicy: jej postać znikła tak, jak znikło jej imię (przynajmniej w tytule; krótka uwaga Hantaïa kończy się „Dla Madonny del parto"19). To malarstwo poświęcone malarstwu. Jak można zauważyć, odnosi

17 Po obejrzeniu tej Madonny Chagall w 1913 roku namalował Kobietę brzemiennq (Amsterdam, Stedelijk Museum). Postaci palcem wskazują swoje łono, na którym widać niewielką postać umieszczoną w owalu (zgodnie ze wspomnianą wyżej wschodnią tradycją). Por. I. Walter Piero della Francesca. Madonna del parto, Fischer Taschenbuch, Frankfurt am Main 1993, s. 13. Ciekawe wydaje się również wskazanie kilku wspólnych punktów z Nawiedzeniem Pontormo: dysproporcje między główną postacią a tłem, niewielkie postaci męskie, rozkład światła. (Ostatecznie Carmignano ma w sumie sporo wspólnego z Monterchim...). Można odesłać również do innego cytatu z dzieła Piero della Francesca, czyli Autoportret/Wypowiedzenie Agnès Thurnauer (1999), gdzie na najbliższym planie ręka wsuwa się w szczelinę sukni.

Istnieje wiele historycznych, malarskich i psychoanalitycznych komentarzy poświęconych tym problemom. Tutaj chciałbym wskazać, w jaki sposób Hubert Damisch podkreśla fakt, że scena ta "nie ma zewnętrza", która jest w rzeczywistości sceną wciąż zamkniętego łona, zarazem dziewiczego i zapłodnionego. Wykazuje on również, że różne obrazy Nawiedzenia są z definicji scenami „bez Ojca”, tak jak np. scena z konkretnie tą Madonną. Por. H. Damisch Un souvenir d'enfance par Piero della Francesca, Seuil, Paris 1997, s. 104 i 102.

Donation Simon Hantaï, Muzeum Sztuki Nowoczesnej, Ville de Paris, 1998. Tytuł "del parto" poprzedza elipsa po stronie reprodukcji dzieła (s. 30), ale nie we wstępie autorstwa Susan Page (s. 3). Należy również przypomnieć inny ważny cykl Hantaïa zatytułowany Mariales; z kolei jedno z płócien nosi tytuł ...dell'Orto i zadedykowane jest Tintoretto. Tytuł ten podkreśla znaczenie odniesienia do przeszłości malarstwa. Nie zatrzymuję się tutaj nad związkiem tego zbioru 
się ono jednak bardziej do powtórzenia i nowego obrazu odwiecznego łona (bądź, by tak rzec, łona tego, co odwieczne), niż jakiejkolwiek pamięci tego malarstwa. Odwieczne łono, łono tego, co odwieczne, okazuje się zatem samym malarstwem - jego rozpostartą powierzchnią i masą - przedstawionym nie tyle po to, byśmy mogli ujrzeć narodziny (pojawiającą się postać), lecz po to, by umożliwić do niego dostęp, który jest niczym innym jak samym otwarciem pikturalnej przestrzeni. Zwracając się w ten sposób ku własnej tradycji, owa przestrzeń nie odnosi się do żadnej „treści” (czy znaczenia), lecz jedynie do swej płaszczyzny i swego pofałdowania, podlegając zmianom w nieskończonym ruchu wznoszenia obecności zawsze-już obecnej w głębi, obecności głębi jako takiej, obecności otwartej na samą siebie, aż do najskrytszej podstawy, stanowiącej w rzeczywistości nic innego jak to właśnie rozsunięcie i oddzielenie.

Hantaï opisuje, w jaki sposób tworzy swoje płótno, które zwija i splata, zanim położy farbę; na koniec tego procesu „węzły zostają przemieszczone i rozwinięte, a wyściółka otwiera się w każdej szczelinie i w każdym kierunku". Tym samym płótno równocześnie przyjmuje formę (wszelako na tej samej płaszczyźnie) podwójnie rozciętej sukni oraz zapikowanej apsydy namiotu. Wyjście na powierzchnię obrazu powoduje, że wszystko przechodzi przez tło obrazu. Podobnie jak u Piero della Francesca i Pontormo (ale być może w całym malarstwie) u Hantaïa zwinięta sekretność podmiotu malarstwa (tajemniczej obecności, tajemnicy rzeczywistej obecności) rozwija się i rozpościera na płaszczyźnie malowidła. Toteż wzniesiona w ten sposób napięta i bardzo duża powierzchnia $(255 \times 320 \mathrm{~cm})$ to nic innego jak miejsce owych szczelin, ich świetlistego tańca, ich trzeszczących ruchów odciskających się w kolorze, który Hantaï lubił sam określać jako „caput mortuum” ${ }^{20}$ i wymieniał go na liście

dzieł ze znaczeniem intaglio (entaille), jako że problem ten podjął już Georges Didi-Huberman w książce L'Étoilement, Minuit, Paris 1998.

20 Dzięki Samii Benhaddou i François Martinowi mogę sprecyzować swoje stanowisko: termin ten - (tak jak tête morte ["Trupia czaszka"], tête de momie ["Czaszka mumii"] czy tête de Maure ["Głowa Maura"] - w XIX wieku, kiedy kolor powstawał z resztek po mumiach, odnosił się do ciemnego czerwonobrązowego koloru („powstały w wyniku końcowych działań z tlenkiem żelaza kolor ten stanowi jeden z czerwonych odcieni tego metalu. Sytuuje się dość blisko czerwieni angielskiej, weneckiej oraz indyjskiej", jak zauważył w liście do mnie malarz, Bruno Carbonnet). Słowo ma swoje źródła w alchemii, gdzie oznaczało ostateczną resztkę, wytracającą się z chemicznych operacji, ,tego stadium dzieła, kiedy wszystko wydaje się przegniłe, a jednak wszystko się odrodziło". M. Leiris Zébrage, Gallimard, Paris 1992, s. 41, oraz odniesienie do Hegla. 
materiałów do gruntowania obrazu. Grunt, ziemia, światło - światło ziemi (a nie niebios) - śmierć, życie, głębia i otwarcie.

(Uwaga po fakcie: dodaję poniższe zapiski Hantaïa z nowszej publikacji²1: „To, co się ukrywa, zarazem się odsłania - zwinięte w skrytości... Płótno przestaje być e kra n e m projekcji, staje się materialne, odcina się od siebie itd. - wklęśnięty - wpuklony - spłaszczona góra - namalowane i ukryte - zwijanie i rozwijanie... pustka, oddzielająca i wiążąca... za tym nie ma nic).

Malarstwo otwiera się na siebie, otwierając się tym samym na to, co odwieczne - obecność zawsze-już-tu i zawsze-tu-od nowa, nieskończenie wycofana w samą siebie, niestrudzenie wystawiana przed nami, łono przeszyte na wskroś wewnętrznym drżeniem: my sami przed naszymi narodzinami, po śmierci, zawsze od nowa, w olśniewającej anamnezie, która jest zarazem poddana amnezji i hipermnezji, n i e - p a m i ęć świtu i zmierzchu świata.

Opowieść o własnych narodzinach, którą stworzyło malarstwo - grecka historia o młodej dziewczynie, która obrysowała na murze cień swojego narzeczonego wyjeżdżającego na wojnę - to nic innego jak parabola reprezentacji. Dziewczyna ta nie stara się reprodukować obrazu kogoś, kto jest już nieobecny w danym miejscu, aby go sobie później przypomnieć, lecz raczej unieruchamia cień, mroczną obecność, znajdującą się w tym miejscu o tyle, o ile jest tam światło, kopię rzeczy - każdej rzeczy - oraz jej niewidzialną podstawę i głębię. Malarstwo nie czyni głębi widzialną, lecz powoduje, że staje się ona niewidzialna w świetle, nosi w sobie i rozsiewa niewidzialność w pigmentach oraz fałdach jej iluminacji. Tym samym jednak malarstwo nosi w sobie prawdę reprezentacji: chodzi w tym przypadku o „reprodukcję” o tyle, o ile jest ona przede wszystkim - zarówno w swym koniecznym ruchu, jak i podstawowym znaczeniu słowa „reprezentacja”, czyli uobecnienie - intensywnością przedstawienia, które przenika pragnienie, by wydobyć na światło dzienne obecność poprzedzającą dzień.

Jeśli owo Nawiedzenie Pontormo skupia w sobie całą swoją energię - znaczeniową, symboliczną, polityczną, seksualną, emocjonalną, metafizyczną czy estetyczną - w wirze opalizujących materiałów, w które zostaje ona spowita, tańczących na pierwszym planie scen, pozwalających ją zarazem rozpoznać i zakryć, to dzieje się tak dlatego, że malarstwo w tym przypadku zwija się i rozwija się w sobie i na sobie osiada; to rodzaj otuliny lub zasłony na jego geschichte, Münster, 1999 (słowa „inwolucja/wklęśnięcie” i „wpuklenie" można znaleźć w cytowanym wyżej, w przypisie 18, studium Damischa). 
własnym łonie, które niosą ze sobą obecność odwiecznej nieobecności. Nawiedzamy tę obecność w migotaniu, dotykanym przez nasze oczy.

Co to jest malarstwo chrześcijańskie? Z pewnością nie jest przedstawieniem chrześcijańskich przypowieści. W historii malarstwa pojawiła się również i taka kwestia, lecz był to właśnie problem reprezentacji (w jej istotowym sensie, a nie znaczeniu ilości malarskich przedstawień), nie zaś wszelkich innych mitologicznych i heroiczno-politycznych narracji. Chodzi tu o reprezentację o tyle, o ile każdy rodzaj ilustracji spełnia swoje zadanie na wzór religijnych obrazów, które (reguła ogólna) mają tym mniejszą wartość artystyczną, im bardziej są religijne. Malarstwo chrześcijańskie nie jest reprezentacją chrześcijańskich treści. Całkiem odwrotnie: malarstwo chrześcijańskie to chrześcijaństwo (lub pewna część chrześcijaństwa w malarstwie bądź jako malarstwo) leżące u podstaw malarstwa: tworzy malarstwo brzemienne, daje mu życie, a zarazem zwiastuje swoją w nim obecność i utożsamia się z nim, a co więcej: chrześcijaństwo w malarstwie i jako malarstwo to zapowiedź całego wyzwania i całej historii, które po dziś dzień określamy mianem „sztuki".

Nie jest prawdą, że chrześcijaństwo rozwinęło swoje obrazowanie poprzez ilustrowaną Biblię przeznaczoną dla niepiśmiennych. Obraz chrześcijański, związany z nie mniej chrześcijańskim odrzuceniem obrazu - wewnętrzne rozdarcie i zszycie na nowo chrześcijaństwa oraz wszystkich trzech monoteizmów - niesie ze sobą całą intensywność dostępu do niedostępnej boskości: do bezimiennego boga, najwyższego, który nie osiąga żadnej wysokości, do obecności bez obecności, odpodobnionego obrazu oraz pozoru lub zjawy pozbawionych obrazu, zjawy, której przedmiotem jest to, co się nie zjawia, nie-zjawianie się oraz zawieszenie wszelkiej fenomenologii - malarstwo jako o f i a r o w a n i e: dosłownie, „wystawienie na przód”.

W rzeczywistości chodzi o chrześcijaństwo o tyle tylko, o ile ono samo siebie dekonstruuje, tzn. o tyle, ile wycofuje się z religii, z jej opowieści i wierzeń, by stać się niepokojem niepamiętnej i odwiecznej teraźniejszości: bogowie wycofali się, wycofując wraz ze sobą obecność jako taką. Prawda monoteizmu to ateizm tego odejścia. „Rzeczywista obecność” staje się obecnością, która w sensie ścisłym nie jest obecna: to obecność tego, kogo tu nie ma. Ktoś, kogo bycie-tu jest byciem (co oznacza w tym miejscu: sposób działania, manierę, dotyk, błysk, linię czy kontur) wyeksponowanym na działanie zewnętrzności samego tego miejsca, w którym wszelako nie ma żadnego widzialnego ani niewidzialnego zewnętrza, owego „gdzie indziej”, wprost na płótnie, „tu”: niczym w nabrzmiałym łonie malarstwa. Malarstwo ofiarowuje: o to c i ało 
m o j e. To ekspozycja skóry lub przesłony, pod którymi żadna obecność się nie ukryje, żaden bóg nie oczekuje poza tym właśnie miejscem, tu oto, a rozkosz i cierpienie wynikłe z bycia w świecie to szczególny dotyk naszej własnej ekspozycji - właśnie tu i nigdzie indziej.

W tym znaczeniu malarstwo chrześcijańskie trzeba pomyśleć - tzn. rozpatrzyć, ocenić i rozkoszować się nim - z jednej strony jako coś, co zostało włączone w całość malarstwa zachodniego na podstawie motywów chrześcijańskich ${ }^{22}$ : całe malarstwo „świeckie” oraz, ogólnie biorąc, wszystkie tryby malarstwa i sztuk wizualnych czy plastycznych upowszechniają i dzielą, ożywiają i problematyzują ową figurę hoc est corpus meum. Każde z tych słów nabrzmiewa od nadziei, aporii, pewników i rozczarowań, radości i cierpień dotyczących „rzeczywistej obecności”, która wcale nie jest „obecna” $i$ „rzeczywista", jak to mogły sobie niegdyś wyobrażać empiryczne gwarancje or a z wierzenia religijne. Malarstwo - sztuka - polega jednak na tym, że opuszcza ten stary świat: z miejsca, właśnie tu. (Czy istniał kiedykolwiek ów „stary świat" naiwnej oraz wyobrażonej wiary? Czy nie jest to raczej nasza retrospektywna iluzja, nas, chcących zawsze mieć przeszłość, poza którą można wykroczyć albo którą można stracić?...).

Lecz również (z drugiej strony): malarstwo chrześcijańskie, a wraz z nim samo chrześcijaństwo, trzeba traktować jako gęste i złożone wprowadzenie potrójnej instancji obecnej w monoteizmie, odtwarzanej również wewnątrz chrześcijaństwa jako potrójna instancja tego, co katolickie, ortodoksyjne i protestanckie - bóg chrześcijański „ściśle” (to znaczy, religijnie) mówiąc, obecny/ukryty i prezentujący się jako ukryty; bóg żydowski, mówiący, zapytujący spoza niewymawialności i niewidzialności; bóg muzułmański, niewspółmierny z żadną obecnością. Wspólne dla tych trzech tradycji jest przymierze. Istnieje zatem zawsze przymierze $\mathrm{z}$ tym, co zasadniczo nie przystaje do jakiegokolwiek przymierza i jest całkowicie do niego niezdolne w znaczeniu związku czy jakiejkolwiek jedności. Dlatego właśnie w sercu malarstwa - a chodzi tu w istocie o jego serce - rozgrywa się nieskończona wymiana między reprezentacją i nie-reprezentacją, widzialnym a nie-widzialnym, sztuką a odrzuceniem sztuki. Spróbujmy rozważyć przez chwilę Nawiedzenie Pontormo jako obraz żydowski: rzeczywiście, nie wypełnia on reprezentacji przedmiotem, o którym traktuje (to nakaz tradycji, aby reprezentacja pozostała niekompletna). Wyobraźmy sobie teraz ten obraz jako malowidło 
muzułmańskie: faktycznie, składa się nań tylko - również nieskończony chaos arabesek.

Tak oto malarstwo o d p a mi ię $\mathrm{n}$ i a to, czego pamięcią nie jest trojaki monoteizm: to, co, poczynając od siebie, musi zostać od siebie uwolnione, ale długo przed nim samym oraz przed nami - nasza własna rzeczywista obecność wycofała się z nas.

W jaki sposób stajemy się brzemienni: jak nabrzmiewa i ukazuje się w nas i przed nami - to oczekiwanie, które wartość znajduje nie tylko, być może w ogóle, w spełnieniu, lecz raczej w „tu i teraz”. Oczekiwanie nieoczekujące niczego, które nie podlega na nadejściu, narodzinach, malarstwo, które niczego nie maluje, tzn. poza reprezentacją i samym spojrzeniem: bycie-tu-oto „tego, co poza" [être-là de l'au-delà]. O co innego mogłoby chodzić, tu i teraz?

W pewien sposób bycie-tu-oto „tego, co poza" przybiera formę podsumowania chrześcijaństwa ${ }^{23}$, a być może także punktu wyjścia (w nim samym) do jego własnej dekonstrukcji, tzn. do jego własnego odarcia z charakteru religijnego, natychmiast otwierającego się w zadziwiającej dwuznaczności, strukturyzującej podwójną możliwość świata (jeśli przyjmiemy, że zaczyna się on wraz z Zachodem): z jednej strony, nihilizm (kiedy „tu-oto” wchłania „to, co poza”), a z drugiej - wieczność, jeśli można ją rozumieć jako „to, co poza”, zmierza ku otwarciu „tu-oto”, dając mu swoje „bycie-tu-oto” w samym tym otwarciu. (Z tym samym próbowały poradzić sobie filozofie: Heideggera, co widać w pojęciu Dasein, Derridy - différance, czy Deleuze'a - stawanie-się-niedostrzegalnym, lub co widać - już bez nazw własnych - w wysiłkach współczesnego świata, który usiłuje po Auschwitz i Hiroshimie, po katastrofach i za ich pośrednictwem przemyśleć wszelkie tożsamościowe, wspólnotowe, suwerenne i skapitalizowane deklaracje oraz twierdzenia, polegające na tym, że nakładają owo „tu-oto" na „poza” zamiast zapisać „poza” jako „tu-oto”).

Te próby i wysiłki myśli, ten wspólny wysiłek praxis sensu, której wyrzeka się theoria w znaczeniu „narzucenia przedmiotu", zakłada konieczne odwołanie się do obrazu: ponieważ obraz w takiej formie, w jakiej wypracowała go nasza chrześcijańska historia, działający i bezczynny, nawiedzany

23 W tym znaczeniu to, co tu zarysowuję, łączy się, przynajmniej po części, z tezami zawartymi w znakomitej pracy Marie-José Mondzain o chrześcijańskim pochodzeniu refleksji nad obrazem - oraz/lub wcieleniu - zgodnie z "pojęciem obrazu, który wymaga pustki w sercu widzialności". M.-J. Mondzain Image, Icône, Économie - les sources byzantines de l'imaginaire contemporain, Seuil, Paris 1996, s. 268. Niestety nie mogę wiele dodać do powyższych uwag, ponieważ o istnieniu tej książki dowiedziałem się, kiedy tekst ten byłjuż prawie ukończony. 
i opuszczony, obraz (nieograniczający się do malarstwa, występujący także w muzyce, tańcu, a także w kinie, fotografii, sztuce wideo itd.) jest w stopniu najwyższym „tu-oto" pewnego „p o z a”. Obraz nie jest w ogóle „reprezentacją": stanowi myśl-tu-oto, myśl jako rzeczywistość miejs c a otwierającego się na obecność.

Malarstwo „chrześcijańskie” (w zachodniej części chrześcijaństwa), które przestało być w ścisłym sensie religijne i funkcjonować jako przedmiot kultu, nie stało się mimo wszystko „przedstawiające” (nie jest ani „realistyczne”, ani podporządkowane „podobieństwu”). Nie przestało, mimo wszystkich przekształceń i przemieszczeń, jakich dokonały w jego ramach sztuka malarska i wszelkie sztuki obrazu, drążyć tego miejsca otwarcia, dającego przestrzeń temu, co nie ma miejsca: obecności jako tego, co istotowo stanowi przekroczenie. Chodzi zatem o obecność jako to, czego nie można uobecnić lub to, do czego nie ma właściwie dostępu, tyle że jest to obecność po Auschwitz i Hiroshimie, po katastrofach i za ich pośrednictwem, jako to, co, będąc ofiarowanym w nawiedzeniu, doświadcza niewidzialności w swym sercu, a precyzyjniej: doświadcza tego, co patrzy na nas spoza głębi swego serca lub spoza głębi owego działania, które zwiemy „sztuką” i przez które oznaczamy nic innego jak podzielony i rozdarty dostęp do naszej wspólnej obecności. To właśnie dzięki niej możemy nawiedzać się nawzajem, tzn. zbliżyć się do siebie i siebie dojrzeć, my, którzy jesteśmy obecni, my - niepamiętni.

Zaskakujące, że żydowski (być może judeochrześcijański?) myśliciel, taki jak Emmanuel Levinas, mógł napisać: „Owa obecność [Innego] polega na tym, że przychodzi do nas, t w o r zy w e j ś c i e. Można to określić następująco: fenomen, jakim jest widmo Innego, to również twarz bądź (by pokazać to nieustannie nowe wejście w immanencję oraz istotową historyczność zjawiska): epifania twarzy to nawi edzeni $\mathrm{e}^{24}$.

Przełożył Jakub Momro 


\section{Abstract}

\section{Jean-Luc Nancy}

Visitation: OfChristian Painting

Nancy proposes a detailed analysis of a painting by Pontormo and discusses the echoes of this representation in contemporary art. His philosophical reading of Christian paining is part of his project to 'deconstruct Christianity' - a project whose theoretical foundations are the studies Déclosion: Déconstruction du christianisme 1 [Dis-Enclosure: The Deconstruction of Christianity l] and Adoration: Déconstruction du christianisme 2 [Adoration: The Deconstruction of Christianity II]. Nancy's goal is to 'take apart' the metaphysical foundations of representation - not only in painting but also in the sense of questioning the very principle of representation in Western culture. The philosopher's critical look at the painting allows him to bring to the surface its singular materiality, which is the suppressed element of religious, theological and metaphysical thought. But at the same time, this kind of thinking does not cease to trouble us, that is to say to 'haunt' us like a spectre of ourselves, immersed as we are in the post-metaphysical world.

\section{Keywords}

image, deconstruction of Christianity, haunting, materialism 